\title{
Anti-inflammatory effect of Polygonum multiflorum extraction in activated RAW 264.7 cells with lipopolysaccharide
}

\author{
Lee Eunsu' ${ }^{1}$ Kim Hyeongjeong ${ }^{1,2}$, Jae-myo $\mathrm{Yu}^{1}$, Yong-hun Cho ${ }^{1}$, Dong-in Kim ${ }^{1}$, \\ Shin Yuhyeon ${ }^{1,2}$, ChoYeongje ${ }^{3}$, O-jun Kwon ${ }^{4}$, An Bongjeon ${ }^{1 *}$ \\ ${ }^{1}$ Department of Cosmeceutical Science, Daegu Hanny University, Gyeongsan 712-715, Korea. \\ ${ }^{2}$ Institute of Technology, Herbnoori Co., Lt., Daegu 702-852, Korea \\ ${ }^{3}$ School of Food Science and Biotechnology / Food and Bio-Industry Research Institute, Kyungpook National University, \\ Daegu 702-701, Korea \\ ${ }^{4}$ Regional industry Evaluation Agency for Gyeongbuk, Andong 712-210, Korea
}

\section{Lipopolysaccharide로 활성화된 RAW 264.7 세포에서 적하수오(Polygonum multiflorum) 추출물의 항염증 효과 검증}

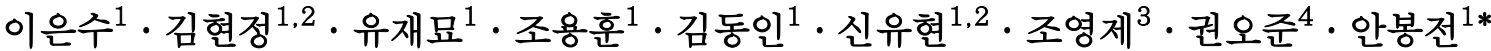 \\ ${ }^{1}$ 대구한의대학교 화장품약리학과, ${ }^{2}\left(\right.$ 주)허브누리 기술연구소, ${ }^{3}$ 경북대학교 식품공학부/식품생물산업연구소 \\ ${ }^{4}$ 대경지역사업평가원/경북지역산업평가단
}

\begin{abstract}
The anti-inflammatory effects of Polygonum multiflorum water extracts (PMWs) and Polygonum multiflorum 70 $\%$ ethanol extracts(PMEs) were investigated using lipopolysaccharide-induce by inflammatory response. The inhibitory effects of PMWs and PMEs on the production of nitric oxide (NO) and pro - inflammatory cytokines in LPS - activated Raw 264.7 cells were investigated. The effects were examined after reducing production of Nitric oxide (NO), prostaglandin $\mathbf{E}_{2}\left(\mathbf{P G E}_{2}\right.$ ), interleukin-6 (IL-6), tumor necrosis factor-a (TNF- $\alpha$ ), interleukin-1 $\beta$ (IL-1 $\beta$ ), nitric oxide synthase (iNOS) and cyclooxygenase-2 (COX-2) protein levels. RAW 264.7 cells were cultured with LPS $(1 \mathrm{\mu g} / \mathrm{mL})$ in the presence or absence of PMWs and PMEs for $24 \mathrm{~h}$ to determine their NO, iNOS, COX - 2 levels. During the entire experimental period 10, 25, 50 and $100 \mu \mathrm{g} / \mathrm{mL}$ of PMWs and PMEs showed no cytotoxicity. At these concentrations, PMWs and PMEs concentration dependently reduced the production of nitric oxide (NO), prostaglandin $\mathbf{E}_{2}\left(\mathbf{P G E}_{2}\right)$, interleukin-6 (IL-6), tumor necrosis factor- $a$ (TNF- $\alpha$ ) and interleukin-1 $\beta$ (IL-1 $\left.\beta\right)$. PMWs and PMEs were inhibited the activittion of iNOS, COX-2 by $89 \%, 54 \%, 91 \%$ and $57 \%$ respectively, at $100 \mu \mathrm{g} / \mathrm{mL}$. These results indicate that PMWs and PMEs significantly reduces the effect of oxidative and inflammatory cytokines.
\end{abstract}

Key words : anti-inflammatory, COX-2, cytokine, iNOS, Polygonum multiflorum

\section{서 론}

염증은 생명체의 생로병사의 과정에서 중요한 병리적 요소로 작용하며, 급성 염증은 화학적 혹은 물리적 자극 등에 대항하는 인체의 방어 기전이며, 조직이나 장기의 손 상을 회복시키는 기전으로서 중요한 역할을 담당하고 있 다. 염증이 유발되는 과정은 그 자체로는 질병으로 취급받

*Corresponding author. E-mail : anbj@dhu.ac.kr Phone : 82-53-819-1435, Fax : 82-53-819-1435
지 않지만, 장기간 지속 할 경우 다른 질환을 유발하는 원인으로 작용하기도 한다(1). 또한, 세포 및 자극의 종류에 따라 $\mathrm{PG}$ (prostaglandin), $\mathrm{LT}$ (lekotrine) 등이 생성됨으로써 시작된다(2). 대식세포는 대표적인 면역세포로써(3), 동물 체내 모든 조직에서 분포하며, 세균이나 이물질을 탐식 제 거하는 과정에서 IL-1 $\beta$ (Interleukin 1- $\beta$ ), IL-6(interleukin-6), TNF- a(tumor necrosis factor- $a$ ) 등의 염증 매개 물질들을 분비하여 초기 염증 반응에 주요 역할을 담당한다 $(4,5)$. 또 한, iNOS(inducible nitric oxide synthase)와 COX-2(cyclooxygenase- 
2)의 발현을 유도하여 $\mathrm{NO}$ (nitric oxide) 및 $\mathrm{PGE}_{2}$ (prostaglandin $\left.\mathrm{E}_{2}\right)$ 와 같은 염증성 인자가 생성됨으로써 염증반응이 매개 된다(6,7). 구체적으로 살펴보면, NO는 체내 방어기능, 신 호전달기능, 신경독성, 혈관 확장 등의 다양한 생리기능을 가지고 있으며, 3종류의 NOS(nitric oxide synthase), nNOS(neuronal nitric oxide synthase), eNOS(endoterial nitric oxide synthase), iNOS(inducible nitric oxide synthase) 에 의 해 합성된다. 이들 NOS 중 $\mathrm{iNOS}$ 에 의한 $\mathrm{NO}$ 생성이 절대적 으로 많으며 이는 병리적으로 중요한 작용을 한다(8). 과도 한 NO생성은 염증반응을 촉진시킬 뿐만 아니라 염증매개 체의 생합성을 촉진하고 염증을 심화시켜 조직의 손상, 유 전자 변이 및 신경손상 등을 일으킨다 $(9,10)$.

최근 사회가 발전함에 따라 사람들의 건강에 대한 관심 도가 급증하면서 피부 트러블을 보완 할 수 있는 천연 항염 증 소재에 대한 관심이 증대되고 있으나 아직 다양한 천연 소재들이 개발되어 있지 않다(11). 이에 본 논문에서는 마디 풀과의 여러해살이풀(Polygonum multiflorum)의 덩이뿌리 로 간을 보하고 신의 기능을 더하여 혈을 보하여 풍사를 제거하는 효능이 있고 간양이 성하여 생긴 풍증, 머리가 희어지는 현상, 어지러운 혈이 허하여 어지러운 증상, 허리 와 무를에 힘이 없음 등을 치료하는 데에 활용 되고 있는 (12-14) 적하수오(Polygonum multiflorum)의 추출방법에 따 른 염증 억제 효과를 실험을 통하여 증명하고, 피부 트러블 을 완화하는 천연 항염증 소재 개발을 위해 본 논문을 활용하고자 한다.

\section{재료 및 방법}

\section{재료 및 시료 추출}

본 실험에 사용한 적하수오(Polygonum multiflorum)는 한 약재 시장에서 구매하여 사용하였다. 적하수오 열수 추출 물 $(\mathrm{PMW})$ 의 경우 $85{ }^{\circ} \mathrm{C}$ 에서 9시간 환류 냉각 추출을 3회 반복 하였고, 적하수오 $70 \%$ ethanol 추출물 $(\mathrm{PME})$ 의 경우 12 시간 동안 침지 추출한 후 여과지(Whatman No. 1)로 3회 반복 여과하였다. 농축 후 동결 건조한 결과 $\mathrm{PMW}$ 의 경우 $35 \%$ 의 수율을 나타내었으며, $\mathrm{PME}$ 는 $25 \%$ 의 수율을 확인할 수 있었으며 냉장실에 보관하면서 본 실험의 시료로 사용하 였다.

\section{시약 및 기기}

세포 배양액인 dulbeco's modified eagle medium (DMEM), fetal bovine serum(FBS), streptomycin penicillin 등의 세포배양용 시약들은 invitrogen사(Carlsbad, CA, USA)에서 구입하였다. 실험에 사용된 시약 중 sodium dodesyl sul-fate(SDS), acrylamide, bisacrylamide는 Bio-rad 사(Hercules, CA, USA)에서 구입하였고, protease inhibitor,
RIPA buffer, griess reagent 등은 Sigma Chemical CO.(St Louis, MO, USA)에서 구입하였다. 실험에 사용된 1차 항체 에는 $\mathrm{iNOS} \mathrm{BD}$ bioscience(Sanjose, CA, USA)와 COX-2 cayman(Ann arbor, MI USA), Glyceraldehyde 3-phosphate dehydrogenase(GAPDH)와 2차 항체인 anti-rabbit Ig-G horseradish peroxidase(HRP), bovine anti-goat IgG horseradish peroxidas(HRP) Santa Cruz사(CA, USA)에서 구입하였다. $\mathrm{PGE}_{2}, \mathrm{TNF}-\mathrm{a}, \mathrm{IL}-6, \mathrm{IL}-1 \beta$ 측정을 위한 ELISA kit는 R\&D systems Inc.(Minneapolis, MN, USA)에서 구입하였다.

\section{세포배양}

RAW 264.7 macrophages cell 배양은 DMEM 배지에 불 활성화시킨 $\mathrm{FBS}$ 를 $10 \%$ 첨가하고 penicillin-streptomycin 100 units $/ \mathrm{mL}$ 첨가 한 것을 사용하였다. 세포는 $10 \sim 12$ 번의 계대 배양을 통해 세포가 안정된 상태에서 진행하였고 배양 기의 온도는 $37^{\circ} \mathrm{C}$ 이였으며 $\mathrm{CO}_{2}$ 는 $5 \%$ 조건에서 사용되었다

\section{MTT assay에 의한 세포 생존율 측정}

RAW 264.7 세포의 생존율을 측정하기 위해 MTT 분석법 으로 세포독성을 측정하였다. RAW 264.7 세포 $5 \times 10^{4}$ cell $/ \mathrm{mL}$ 을 96well plate에 분주하고 PMW, PME를 농도 별 $(\mu \mathrm{g} / \mathrm{mL})$ 로 24시간 동안 처리 하였다. Well당 $20 \mu \mathrm{L}$ 의 MTT 용액을 첨가하여 $37^{\circ} \mathrm{C}, 5 \% \mathrm{CO}_{2}$ incubator에서 4시간 동안 반응시켰다. 배양 후 상등액을 제거하고 MTT 환원에 의해 형성된 formazan에 $\mathrm{DMSO}$ 를 첨가하여 세포를 용해시킨 후 ELISA reader를 이용하여 $540 \mathrm{~nm}$ 에서 측정하였다.

일산화질소(Nitric Oxide) 농도의 측정

대식세포주인 RAW 264.7 세포를 DMEM 배지를 이용하 여 suspension을 $100 \mathrm{~mm}$ cell culture dish에 각 $5 \times 10^{5}$ cell $/ \mathrm{mL}$ 로 조절한 후, $37^{\circ} \mathrm{C}, 5 \% \mathrm{CO}_{2}$ incubator에서 24시간 동안 배양하여 cell을 안정화 시킨 후, RAW 264.7 세포에 $1 \mu$ $\mathrm{g} / \mathrm{mL}$ 의 LPS를 처리하여 1시간 배양한 후 PMW, PME를 처리하여 24시간 배양 한 후 세포 배양액을 수거하여 실험 에 사용하였다. 배양액 $100 \mu \mathrm{L}$ 와 같은 양의 griess reagent를 넣어 10 분간 상온에서 반응 시킨 후 ELISA reader로 540 $\mathrm{nm}$ 에서 흡광도를 측정하였다. Sodium nitrite $\left(\mathrm{NaNO}_{2}\right)$ 의 농 도 별 표준곡선을 이용하여 배양액 내의 NO 농도를 결정하 였다

Western blot을 이용한 iNOS, COX-2 활성 측정

$\mathrm{iNOS}, \mathrm{COX}-2$ protein 활성 측정을 확인하기 위하여 대식 세포주인 RAW 264.7 세포를 DMEM 배지를 이용하여 suspension을 $100 \mathrm{~mm}$ cell culture dish에 각 $5 \times 10^{5}$ cell $/ \mathrm{mL}$ 로 조절한 후, $37^{\circ} \mathrm{C}, 5 \% \mathrm{CO}_{2}$ incubator에서 24 시간 동안 배양하 여 cell을 안정화 시켰다. 세포의 $1 \mu \mathrm{g} / \mathrm{mL}$ 의 LPS를 처리하고 1 시간 뒤에 $10,25,50,100 \mu \mathrm{g} / \mathrm{mL}$ 의 적하수오를 처리하여 
24시간 배양 한 후 배지를 제거하고 배양한 세포들을 cold PBS로 세척 후 $40 \mu \mathrm{L}$ 의 lysis buffer(50 mM HEPES, $\mathrm{pH}$ 7.0, $250 \mathrm{mM} \mathrm{NaCl}, 5 \mathrm{mM}$ EDTA, 0.1\% Nonidet P-40, 1 $\mathrm{mM}$ phenylmethylsulfonyl fluoride, $0.5 \mathrm{mM}$ dithiothreitol, $5 \mathrm{mM} \mathrm{NaF}, 0.5 \mathrm{mM}$ Naorthovanadate)를 이용하여 단백질을 추출한 후 원심 분리하여 상등액을 취하였다. 상등액을 모 아 새 튜브로 옮긴 후 단백질 정량을 하거나 또는 차후 사용하기 위해 $-20^{\circ} \mathrm{C}$ 에 보관한다. 상등액을 bradford assay 로 단백질 농도를 정량 한 후 $8 \% \mathrm{SDS}-\mathrm{PAGE}(50 \mu \mathrm{g} / \mathrm{lane}$ of protein)를 시행하고, 전개된 단백질을 nitrocellulose membrane으로 transfer 시켰다. 1시간 동안 blocking buffer (5\% skim milk in Tris-Buffered Saline Tween-20(TBST))를 이용하여 blocking 시켰고, 1 차 항체 $(1: 1,000)$ 를 희석하여 $4{ }^{\circ} \mathrm{C}$ 에서 overnight한 다음, Tris buffered saline $(10 \mathrm{mM}$ tris- $\mathrm{HCl}, \mathrm{pH} 7.4,150 \mathrm{mM} \mathrm{NaCl}, 0.1 \%$ Tween 20)으로 10 분 간격으로 3 회 세척하고, 각각의 2 차 항체 $(1: 1,000)$ 를 희석하 여 실온에서 1 시간 동안 상온에서 반응시켰다. 다시 TBST 로 10 분 간격으로 3 회 세척 후, 암실에서 ECL(Millipore, Bedford, MA) 용액으로 반응 시켜 Gel Doc ${ }^{\mathrm{TM}} \mathrm{XR}+$ System (Bio $\mathrm{Rad}, \mathrm{CA}, \mathrm{USA})$ 을 이용하여 현상 및 정량을 하였다.

\section{TNF- $a, I L-1 \beta, I L-6, \mathrm{PGE}_{2}$ 생성량 측정}

세포 배양액 내의 TNF-a, IL-1 $\mathrm{T}, \mathrm{IL}-6, \mathrm{PGE}_{2}$ 의 생성량을 측정하기 위해 ELISA kit를 이용하여 실험을 수행하였다. $\mathrm{NO}$ 생성량 측정에 사용했던 동일한 세포배양 상등액을 $\mathrm{TNF}-\mathrm{a}, \mathrm{IL}-1 \beta, \mathrm{IL}-6, \mathrm{PGE}_{2}$ 측정에 사용하였다.

\section{통계처리}

모든 실험은 3회 반복하여 측정하였고, 그 결과는 평균값 \pm 표준편차로 나타냈으며 통계적 분석은 SPSS 10.0(SPSS Inc., Chicago, IL, USA) 프로그램을 이용하여 각 처리구간 의 유의성 $\left({ }^{*} \mathrm{p}<0.05,{ }^{* *} \mathrm{p}<0.01\right)$ 검증을 위해 분산분석 (analysis of variance, ANOVA) 후 tukey test로 다중비교를 실시하였다.

\section{결과 및 고찰}

PMW, PME가 RAW 264.7 세포 생존률에 미치는 영향 마우스 대식세포인 RAW 264.7 cell에 대한의 세포독성 을 확인하기 위하여 MTT assay를 수행하였다. PMW, PME 를 $25,50,75,100,250,500 \mu \mathrm{g} / \mathrm{mL}$ 농도로 24 시간 동안 처리 한 결과(Fig. 1) $100 \mu \mathrm{g} / \mathrm{mL}$ 의 농도까지는 세포 독성이 나타 나지 않았음을 확인하였고 $250 \mu \mathrm{g} / \mathrm{mL}$ 이상의 농도에서는 세포독성을 나타내었기 때문에 $100 \mu \mathrm{g} / \mathrm{mL}$ 의 농도까지를 이용해 다음에 실험들을 진행하였다.

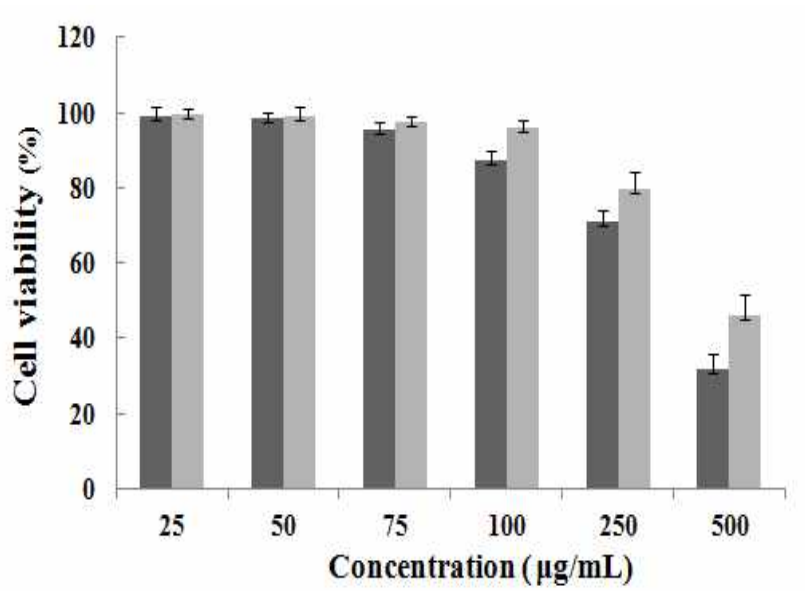

Fig. 1. Cell viability of PMW, PME on RAW 264.7 cell.

RAW 264.7 cells were treated with $25,50,75,100,250,500 \mu \mathrm{g} / \mathrm{mL}$ of PMW, PME dissolved in media for $1 \mathrm{~h}$ prior to the addition of LPS $(1 \mu \mathrm{g} / \mathrm{mL})$, and the cells were further incubated for $24 \mathrm{~h}$. Data represent the mean $\pm \mathrm{SD}$ with three separate experiments

PMW : Polygonum multiflorum water extracts

PME : Polygonum multiflorum $70 \%$ ethanol extracts

[A]

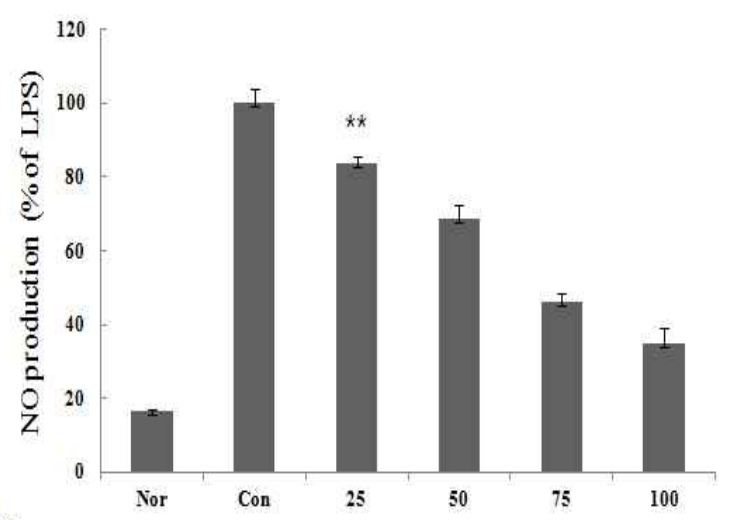

[B]

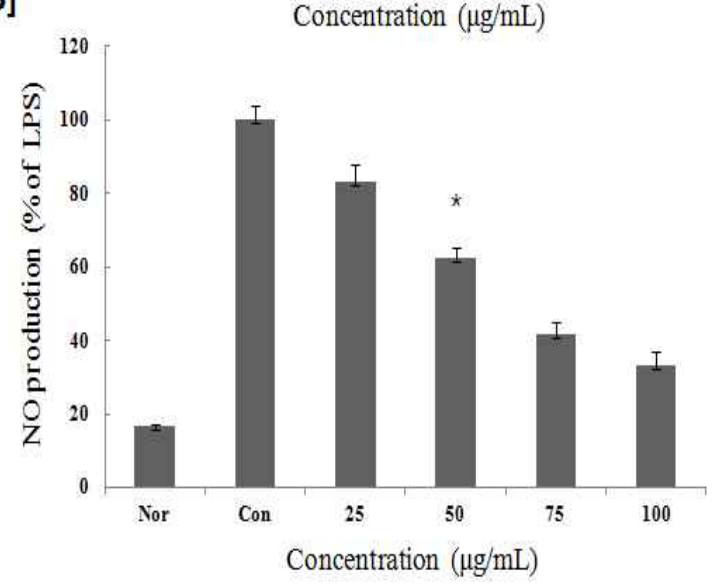

Fig. 2. Inhibitory effects of PMW, PME on the production of nitric oxide RAW 264.7 cells.

RAW 264.7 cells were cultured with LPS $(1 \mu \mathrm{g} / \mathrm{mL})$ in the presence or absence of PMW, PME for $24 \mathrm{~h}$ to determine the level of NO. Nor : LPS not induced group, Con : LPS induced group. [A] PMW : extracted with water. [B] PME : extracted with $70 \%$ ethanol. The data represent the mean \pm SD of three separate experiments (significant as compared to LPS induced group. ${ }^{*} \mathrm{p}<0.05,{ }^{* *} \mathrm{p}<0.01$ ). 
[A]
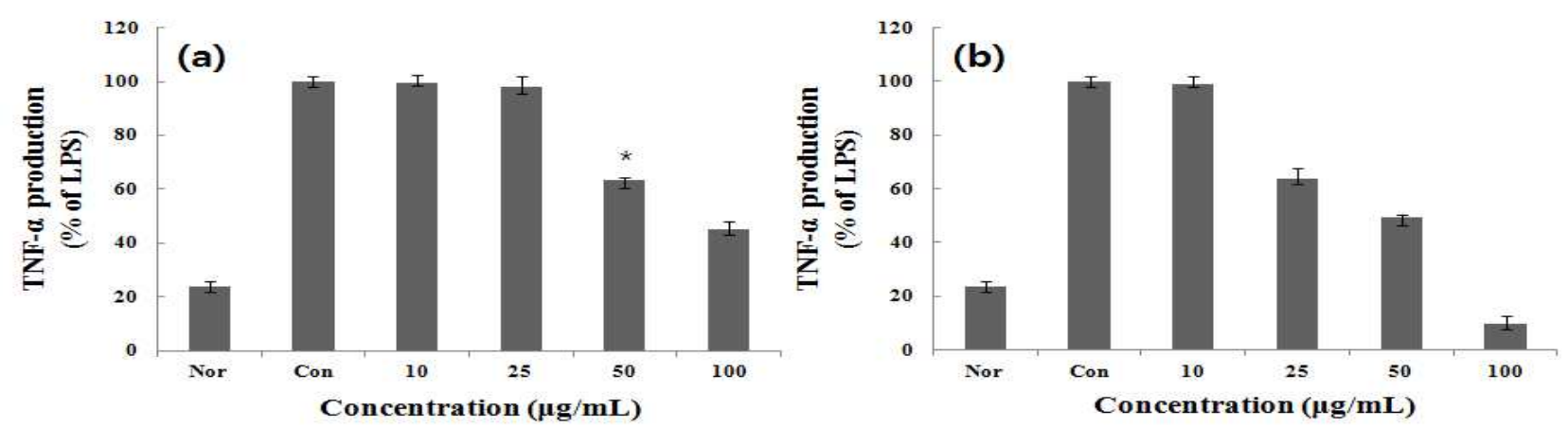

[B]
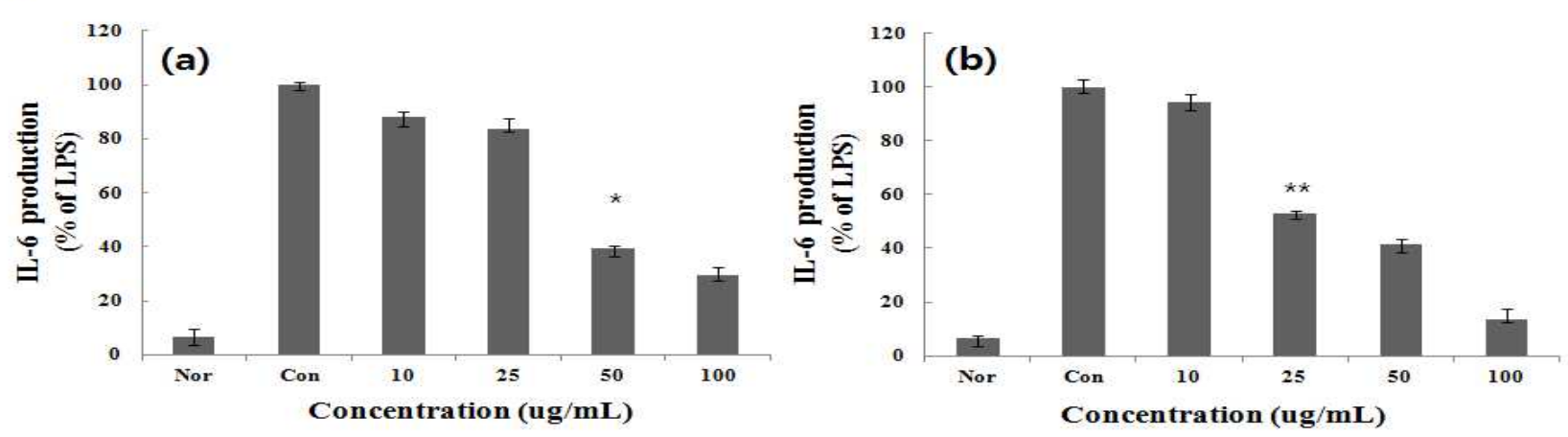

[C]
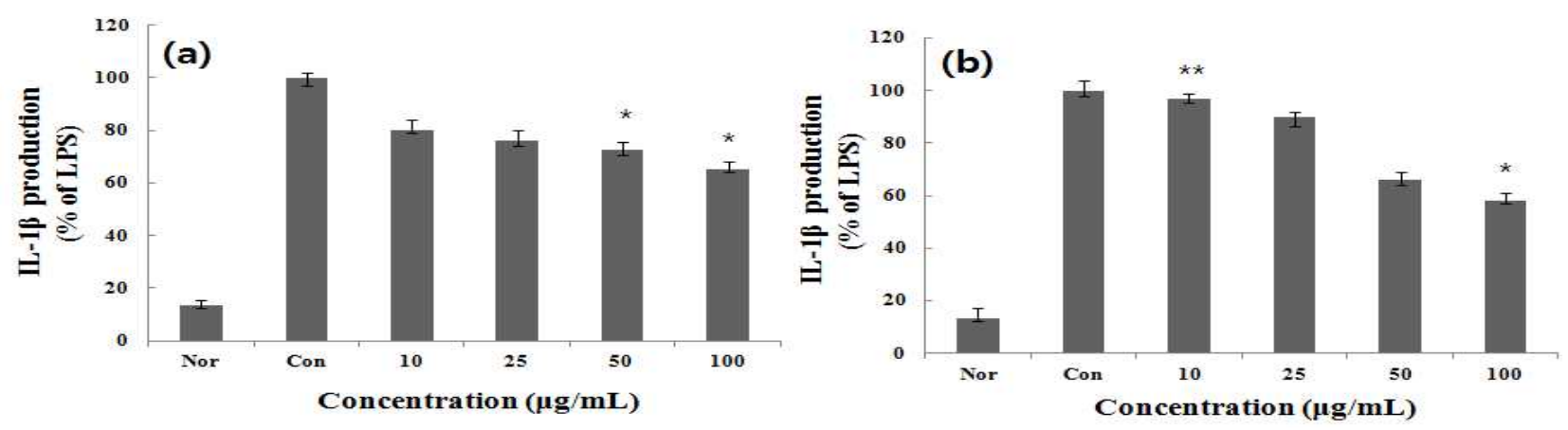

[D]
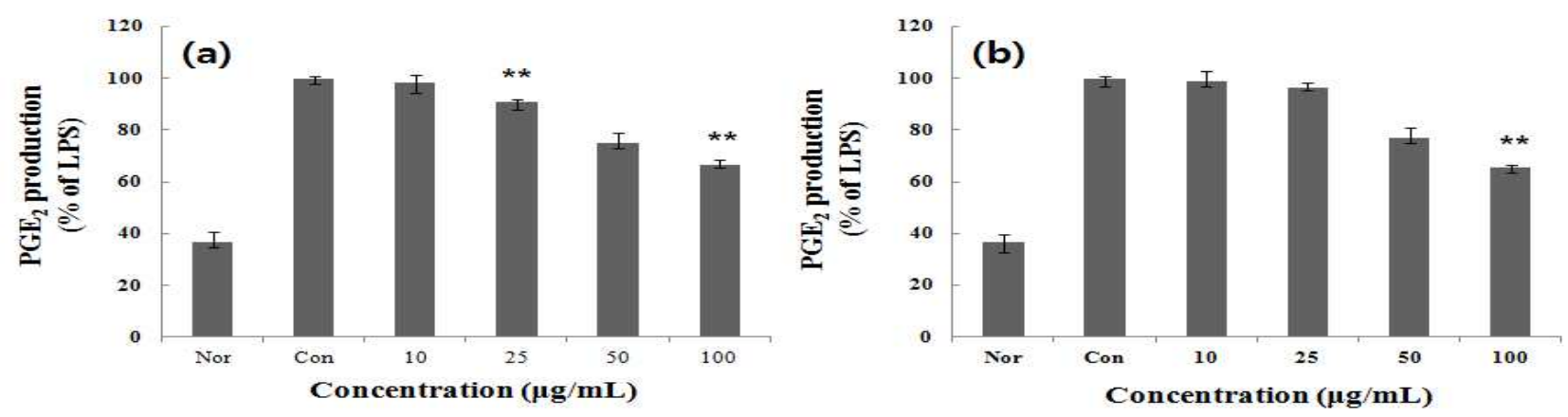

Fig. 3. Effect of PMW, PME on the production of cytokines stimulated by LPS

Production of [A] TNF- $a$, [B] IL-6, [C] IL-1 $\beta$, [D] PGE 2 were measured in the medium of RAW 264.7 cells cultured with LPS $(1 \mu \mathrm{g} / \mathrm{mL})$ in the presence or absence of PMW, PME for $24 \mathrm{~h}$. The amount of TNF-a, IL-6, IL-1 $\beta$, PGE $_{2}$ was measured by immuno assay as described in materials and methods. Nor : LPS not induced group, Con : LPS induced group. (a) PMW : extracted with water. (b) PME : extracted with 70\% ethanol. Data represent the mean \pm SD with three separate experiments. (compared to LPS induced group. $\left.{ }^{*} \mathrm{p}<0.05,{ }^{*} \mathrm{p}<0.01\right)$. 


\section{일산화 질소(NO) 생성억제 효과}

염증상태에서 $\mathrm{iNOS}$ 에 의해 생성된 $\mathrm{NO}$ 는 혈관 투과성, 부종 등의 염증 반응을 촉진시킬 뿐만 아니라 염증매개체의 생합성을 촉진하며(15), 혈관을 확장시키거나 암 조직의 성장을 억제하고, 바이러스나 세균들의 증식을 저해하거나 직접 사멸시키는 등 인체 면역염증반응에 있어서 중요한 역할을 하지만 과잉 배출 시에 만성염증질환 등의 문제점이 발생되기도 한다 $(16,17)$ 항염증 활성을 가지는 물질이나
소재에 대한 연구에서 $\mathrm{NO}$ 의 생성 억제에 대한 검토는 필수 적으로 수행 되어 지고 있다 $(18,19)$. 따라서, $\mathrm{NO}$ 생성에 대한 $\mathrm{PMW}, \mathrm{PME}$ 는 배양액 내의 nitrite 농도를 Griess reagent system을 이용하여 측정하였다. $\mathrm{PMW}, \mathrm{PME}$ 를 농도 별로 세포에 처리하여 생성되는 NO량을 측정한 결과를(Fig. 2) 에 나타내었다. 두 추출물 모두 $75 \mathrm{\mu g} / \mathrm{mL}$ 에서 $50 \%$ 이상의 NO 생성 억제율을 나타내었다.

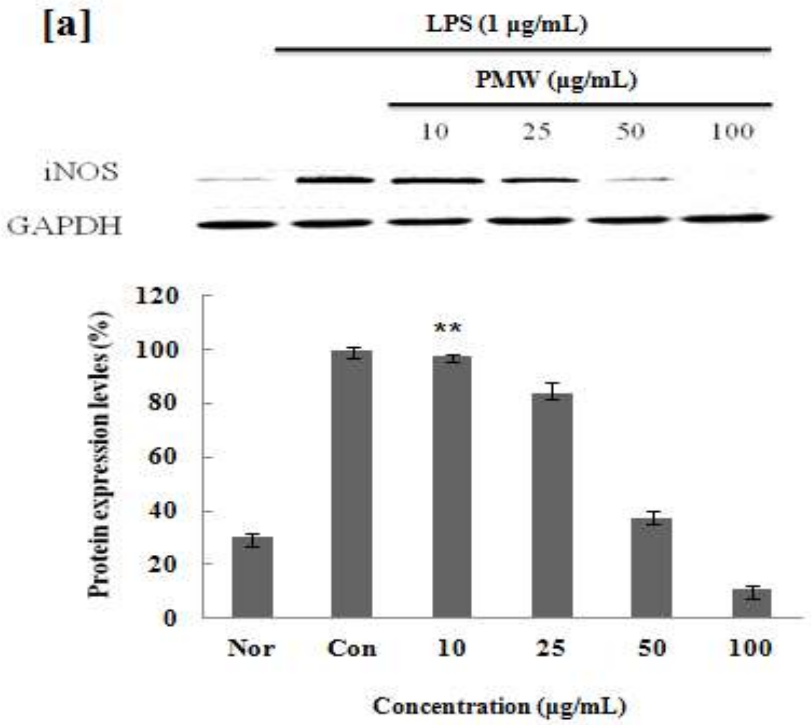

[b]

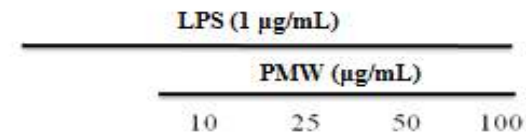

COX-2
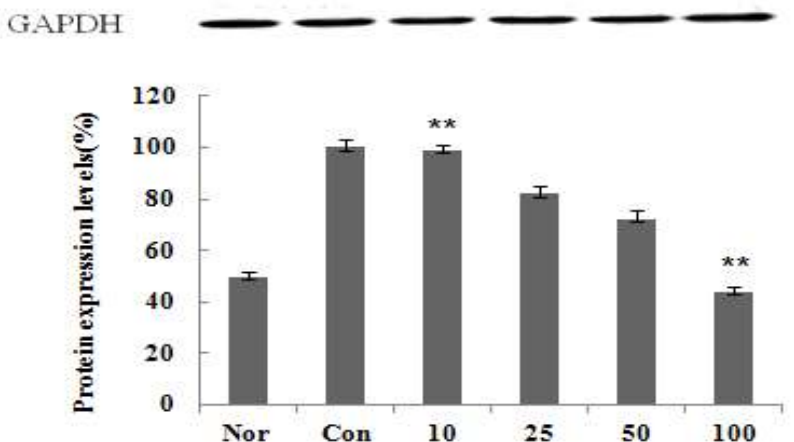

Concentration $(\mu \mathrm{g} / \mathrm{mL})$

Fig. 4. Inhibitory effects of PMW on the protein levels of iNOS and COX-2 in Raw 264.7 cells.

Raw 264.7 cells $\left(5 \times 10^{5}\right.$ cells $\left./ \mathrm{mL}\right)$ were pre-incubated for $24 \mathrm{hr}$, and the cells were stimulated with lipopolysaccharide $(1 \mu \mathrm{g} / \mathrm{mL})$ in the presence of complex extracts sample $(10,25,50,100 \mu \mathrm{g} / \mathrm{mL})$ for $24 \mathrm{hr}$. Nor : LPS not induced group, Con : LPS induced group. Data represent the mean \pm SD with three separate experiments. (compared to LPS induced group. ${ }^{*} \mathrm{p}<0.05,{ }^{* *} \mathrm{p}<0.01$ ).
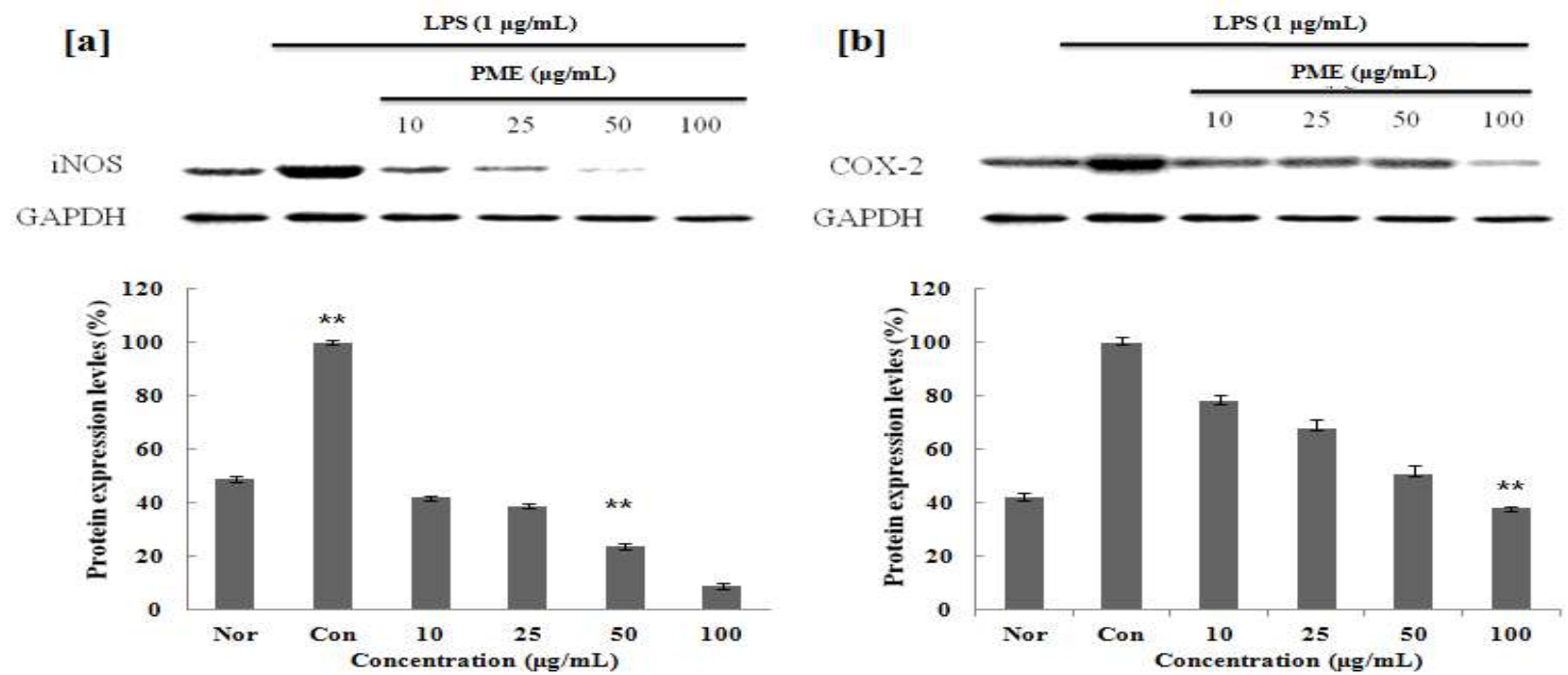

Fig. 5. Inhibitory effects of PME on the protein levels of iNOS and COX-2 in Raw 264.7 cells.

Raw 264.7 cells $\left(5 \times 10^{5}\right.$ cells $\left./ \mathrm{mL}\right)$ were pre-incubated for $24 \mathrm{hr}$, and the cells were stimulated with lipopolysaccharide $(1 \mu \mathrm{g} / \mathrm{mL})$ in the presence of complex extracts sample $(10,25,50,100 \mu \mathrm{g} / \mathrm{mL})$ for $24 \mathrm{hr}$. Nor : LPS not induced group, Con : LPS induced group. Data represent the mean \pm SD with three separate experiments. (compared to LPS induced group. ${ }^{\star} \mathrm{p}<0.05,{ }^{* \star} \mathrm{p}<0.01$ ) 
TNF- $a, I L-1 \beta, I L-6, \mathrm{PGE}_{2}$ 생성 억제 효과

활성화된 대식 세포에서는 IL-1 $\beta, \mathrm{IL}-6, \mathrm{IL}-10, \mathrm{TNF}-\mathrm{a}$ 와 같은 전염증성 및 염증성 사이토카인과 $\mathrm{PGE}_{2}$ 를 생산하게 되는데(20,21), 대식세포는 사이토카인을 분비함으로써 염 증성 반응을 유도하여 이중 TNF-a, IL-6는 면역 반응, 급성 기 반응, 조혈 작용을 조절하는 다면발현성 효과를 보인다 (22). TNF-a 는 다른 백혈구가 염증성 사이토카인을 분비하 도록 자극할 뿐만 아니라 혈관내피세포의 표면에 세포접착 의 발현을 유도하므로 순환중의 백혈구가 유출 되도록 한 다. 특히 TNF- $a$ 의 영향이 전신으로 나타나면 열, 식욕, 감퇴, $\mathrm{C}$ 반응성 단밸질의 상승, 빈혈증을 나타낸다(23). $\mathrm{PMW}$, $\mathrm{PME}$ 가 염증성 cytokine인, TNF-a, IL-1 $\beta, \mathrm{IL}-6, \mathrm{PGE}_{2}$ 의 분 비에 미치는 영향을 알아보기 위해 RAW 264.7 세포에 LPS 처리 한 후 $\mathrm{PMW}, \mathrm{PME}$ 를 농도 별로 처리 한 후 분비된 $\mathrm{TNF}-\mathrm{a}, \mathrm{IL}-1 \beta, \mathrm{IL}-6, \mathrm{PGE}_{2}$ 분비량을 ELISA 방법으로 측정한 결과 $\mathrm{PMW}, \mathrm{PME}$ 는 $\mathrm{LPS}$ 에 증가된 RAW 264.7 cell의 $\mathrm{TNF}-\mathrm{a}$, $\mathrm{IL}-1 \beta, \mathrm{IL}-6, \mathrm{PGE} 2$ 의 생성을 농도 의존적으로 감소시키는 것을 확인 할 수 있었다(Fig. 3).

\section{iNOS, COX-2의 단백질 발현 저해 효과}

염증인자인 $\mathrm{NO}$ 와 $\mathrm{PGE}_{2}$ 의 합성요소인 $\mathrm{iNOS}$ 와 $\mathrm{COX}-2$ 의 발현량에 미치는 영향을 조사한 결과, LPS 처리에 의해 증가된 $\mathrm{iNOS}$ 와 $\mathrm{COX}-2$ 의 발현이 $\mathrm{PMW}, \mathrm{PME}$ 에 의해 농도 의존적으로 감소함을 확인할 수 있었으며(Fig. 4,5), Gel $\mathrm{DocTM}$ XR+ System(Bio Rad)를 사용하여 감소효과를 정량 적으로 확인해본 결과, $100 \mu \mathrm{g} / \mathrm{mL}$ 의 농도에서 $\mathrm{PMW}$ 는 $\mathrm{iNOS}$ 는 $89 \%, \mathrm{COX}-2$ 는 $54 \%$ 의 효과를 나타내었으며, $\mathrm{PME}$ 의 iNOS는 $91 \%, \mathrm{COX}-2$ 는 $57 \%$ 까지 단백질 발현 저해효과 가 있음을 확인 할 수 있었다. 또, $\mathrm{PME}$ 의 경우 저 농도에서 부터 효과를 나타내어 우수한 항염증 소재임을 확인 할 수 있었다.

\section{요 약}

적하수오 추출물의 추출용매별 항염증 작용을 알아보기 위해 LPS로 자극된 RAW 264.7 세포를 이용하여 실험을 진행 한 결과 열수 추출물 및 $70 \%$ 에탄올 추출물 모두 $100 \mu \mathrm{g} / \mathrm{mL}$ 에서 $60 \%$ 이상의 NO 생성 억제 율을 보이는 것을 확인 하였다. 또한 사이토 카인들에 대하여 적하수오 추출 물은 TNF-a, IL-1 $\mathrm{B}, \mathrm{IL}-6, \mathrm{PGE}_{2}$ 생성량은 농도 의존적으로 감소하였고, 이는 적하수오 추출물이 염증성 사이토 카인 의 발현을 억제 하여 염증 발생을 억제 할 수 있다고 할 수 있다. PMW는 $100 \mu \mathrm{g} / \mathrm{mL}$ 의 농도에서 iNOS 단백질 발현 량이 $89 \%, \mathrm{COX}-2$ 는 $54 \%$ 의 효과를 나타내었으며, $\mathrm{PME}$ 는 $100 \mu \mathrm{g} / \mathrm{mL}$ 의 농도에서 iNOS $91 \%, \mathrm{COX}-2$ 는 $57 \%$ 의 단백질 발현 저해효과가 있음을 확인 할 결과로 보아 적하수오는
대식세포에서 NO, TNF-a, IL-1ß, IL-6, $\mathrm{PGE}_{2}$ iNOS, COX-2 발현을 억제 하며, 특히 적하수오 $70 \%$ 에탄올 추출물의 경우 저 농도에서부터 효과를 나타내어 우수한 항염증 소재 임을 확인 할 수 있었다.

\section{References}

1. Higuchi M, Higashi N, Taki H, Osawa T (1990) Cytolytic mechanism of activated macrophages. Tumor necrosis factor and L-arginine-dependent mechanism acts as synergistically as the major cytolytic mechanism of activated macrophages, J Immunol, 144, 1425-31.

2. Hernandez-Ledesma B, Hsieh CC, de Lumen BO (2009) Antioxidant and anti-inflammatory properties of cancer preventive peptide lunasin in RAW 264.7 macrophages. Biochem, 390, 803-8.

3. Yonglimsa (2000) National Professor of Herbology College of Oriental Medicine. Herbology, Seoul, Korea, p 583-4.

4. Hippeli S, Elstner EF (1999) Inhibition of biochemical model reactions for inflammatory processes by plant exreacts: a review on recent developments. Free Radic Res, 31 Supp 1, S81-7.

5. MacMicking J, Xie QW, Nathan C (1997) Nitric oxide and macrophage fuction. Annu Rev Immunol, 15, 323-50.

6. Albina JE, Reichner JS (1999) Nitric oxide in inflammation and immunity. New Horiz, 3, 46-64.

7. Lee YS. Kim HS, Kim SK, Kim SD (2000) IL-6 mRNA Expression in Mouse Peritoneal Macrophages and NIH3T3 Fibroblasts in Response to Candida albicans, J Microbiol Biotechnol, 10, 8-15.

8. Sinilsangsa (2005) Herbal pharmacology textbook compilation committee. Herbal Pharmacology, 755-6.

9. Hirohashi N, Morrison DC (1996) Low-dose lipopolysaccharide (LPS) pretreatment of mouse macrophage in vitro. Infect Immun, 64, 1011.

10. Mu MM, Chakravotty D, Sugiyama, Koide N, Takahashi K, Morei I, Yoshida T and Yokochi T (2001) The inhibitory action of quercetin on lipopolysaccharideinduced nitric oxide production in RAW 264.7 macrophage cells. J Endotoxin Res, 7, 431-8.

11. Won SJ, Park HJ, Lee KT (2008) Inhibition of LPS induced iNOS, COX-2 and cytokines expression by salidroside through the NF-KB inactivation in RAW 264.7 cells. Korean J Pharmacogn, 39, 110-7.

12. Funk CD (2001) Prostaglandins and leukotrienes advances 
in eicosanoid biology. Science, 294, 1871-1875.

13. Ramadori G, Damme JV, Rieder H, Buschenfelde KH (1988) Interleukin 6, the third mediator of acute phase reaction, modulates hepatic protein synthesis in heman and mouse. Comparison with interleukin $1 \beta$ and tumor necrosis factor - a. Eur J Immunol, 18, 1259-1264.

14. Tetley TD (2005) Inflammatory cells and chronic obstructive pulmonary disease. Curr Drug Targets Inflamm Allergy, 4, 607-18.

15. Park SC, Son DY (2011) Inhibitory effects of Euphorbiasupina Eafin on the production of proinflammatory mediator by LPS-stimulated RAW 264.7 macrophages. Food Sci Nutr, 40, 486-92.

16. Maruotti N, Cantatore FP, Crivellato E, Vacca A, Ribatti D (2007) Macrophages in rheumatoid arthritis. Histopathol, 22, 581-6.

17. McCartney-Francis N, Allen JB, Mizel DE, Albina JE, Xie QW, Nathan CF, (1993) Suppression of arthritis by an inhibitor of nitric oxide synthase. J Exp Med, 178, 749-54.

18. Ko SK, Pyo MY (2011) Anti-inflammatory effect of Inonotus obliquus extracts in lipopolysaccharide- induced mouse peritoneal macrophage. Korean J Pharmacogn, 42,
253-259.

19. Lee SJ, Lim KT (2008) Phytogly coprotein inhibits interleukin-1 $\beta$ and interleukin-6 via p38 mitogenactivated protein kinase in lipopolysaccharide-stimulated RAW 264.7 cells. Naunyn schmi Arch Pharmacol, 377, 45-54.

20. Horwood NJ, Page TH, McDaid JP, Palmer CD, Campbell j, Mahon T, Brennan FM, Webster D, Foxwell BM (2006) Bruton's tyrosine kinase is required for TLR2 and TLR4-induced TNF, but not IL-6, production. J Immunol, 176, 3635-41.

21. Kang TB., Yoon TJ (2011) Effect of herbal composition on alcohol degradation and anti-inflammatory activity in mice. Korean J Food Nutr, 24, 489-495.

22. An deokgyun (1999) Gyohaksa, Korean herbology book, Seoul, Korea, 675.

23. Aeberi D, Oertle S, Mauron H, Reichenbach S, Jordi B, Villiger PM (2002) Inhibition of the TNF pathway : use of infliximab and etanercept se remission - inducing agents in cases of therapy-resistant chronic inflammatory disorders. Swiss Med 132, 414-22.

(접수 2014년 5월 21일 수정 2014년 8월 12일 채택 2014년 9월 3일) 